ECOLOGICA, Vol. 28, No 102 (2021), 165-172

https://doi.org/10.18485/ecologica.2021.28.102.4

Originalni naučni rad

UDC: 005:796.032.2(521.27)“2020“

\title{
Menadžment sportskih organizacija i organizacionog komiteta za Olimpijske igre Tokio 2020
}

\section{Management of sports organizations and organizing committee for the Tokyo 2020 Olympic Games}

\author{
Milan Brkin ${ }^{1 *}$, Vojkan Bižić2 ${ }^{2}$ Ana Vukić3 ${ }^{3}$ Srećko Baćevac ${ }^{4}$ \\ ${ }^{1}$ Evropski centar za mir i razvoj Univerziteta za mir UN, Beograd, Srbija / \\ European Center for Peace and Development, UN University for Peace, Belgrade, Serbia \\ ${ }^{2}$ Fakultet za poslovne studije, Univerzitet Megatrend, Srbija / \\ Faculty of Business Studies, Megatrend University, Serbia \\ ${ }^{3,4}$ Alfa BK Univerzitet, Fakultet za menadžment u sportu, Beograd, Srbija / \\ Alfa BK University, Faculty of Sports Management, Belgrade, Serbia \\ ${ }^{*}$ Autor za prepisku / Corresponding author
}

Rad primljen / Received: 26.04.2021, Rad prihvaćen / Accepted: 20.05.2021.

Sažetak: Pandemija COVID-19 veoma je negativno uticala kako na profesionalni, tako i na rekreativni sport u svakom njihovom segmentu. Tokom 120 godina održavanja modernih Olimpijskih igara prateći događaji diktirali su povećanje mera bezbednosti na njima, a posledično i povećanje bezbednosnih zahteva. Do danas se terorizam, kao pretnja celom svetu, pa i Olimpijskim igrama svakako smatrao prioritetnom opasnošću, pred kojom se se sve svetske bezbednosne agencije udruživale u cilju njegovog sprečavanja. Međutim, svedoci smo da se prvi put suočavamo sa novom opasnošću po bezbednost učesnika Olimpijskih igara u vidu pandemije COVID-19, zbog koje je održavanje Igara odloženo za ovu godinu. Predmet ovog istraživanja se odnosi na menadžment sportskih organizacija i organizacionog komiteta za Olimpijske igre u Tokiju pod uticajem COVID-19. Cilj istraživanja je da se kroz analizu rada menadžmenta sportskih organizacija i komiteta sagleda i razume aktuelni problem pandemije COVID-19 i da se kreirane i preduzete mere usvoje i primene i kod organizovanja drugih velikih sportskih događaja. Rezultati rada ukazuju da su sportske organizacije veoma ozbiljno pristupile rešavanju problema, odnosno njihovo angažovanje ukazuje da su mnogobrojnim protokolima i preporukama pokušali da smanje rizik od mogućeg zaražavanja virusom COVID-19 na najmanju moguću meru.

Ključne reči: COVID-19, sportisti, menadžment, bezbednost, sportske organizacije.

\begin{abstract}
The COVID-19 pandemic has had a very negative impact on both professional and recreational sports in each of their segments. During the 120 years of the modern Olympic Games, the accompanying events dictated an increase in security measures, and consequently an increase in security requirements. Until today, terrorism, as a threat to the whole world, including the Olympic Games, was certainly considered a priority danger, in front of which all world security agencies united in order to prevent it. However, we are witnessing that for the first time we are facing a new danger to the safety of the participants in the Olympic Games in the form of the COVID-19 pandemic, due to which the holding of the Games has been postponed for this year. The subject of this research refers to the management of sports organizations and the Organizing committee for the Olympic Games in Tokyo under the influence of COVID-19. The aim of the research is to analyze and understand the current problem of the COVID-19 pandemic through the analysis of the work of the management of sports organizations and committees, and to adopt and apply the created and undertaken measures in organizing other major sports events. The results indicate that sports organizations have taken the problem very seriously, ie their engagement indicates that they have tried to reduce the risk of possible infection with the COVID-19 virus to a minimum with numerous protocols and recommendations.
\end{abstract}


Keywords: COVID-19, management, athletes, safety, sports organizations.

\author{
10rcid.org/0000-0002-4399-9702, e-mail: metalotehnika2000@yahoo.com \\ 2orcid.org/0000-0002-4181-7784, e-mail:vbizic@yahoo.com \\ 3orcid.org/0000-0002-0412-4647, e-mail: ana.vukic@alfa.edu.rs \\ ${ }^{4}$ orcid.org/0000-0002-9580-9667, e-mail: srecko.bacevac@gmail.com
}

\section{UVOD / INTRODUCTION}

Pandemija COVID-19 veoma je negativno uticala kako na profesionalni, tako i na rekreativni sport u svakom njihovom segmentu. Mnogi sportski događaji su odloženi ili otkazani zbog rizika od masovnih okupljanja koja bi pojačala prenos virusa, odnosno zbog rizika kojem bi bili izloženi sportisti i gledaoci (Reade and Singleton, 2020). lako je pandemija COVID-19 još uvek u toku, posle više od godinu dana različitih faza bezbedonosnih situacija/mera, od nametnutog zaključavanja, pa do ograničavanja kretanja i okupljanja, sportisti su počeli polako da se vraćaju u arene, ali sa ograničenim brojem publike. Razmenom iskustava i informacija kreirani su protokoli za održavanje sportskih događaja kako bi se bezbedno bavilo sportskim aktivnostima.

Olimpijske igre kao sportski događaj koji okuplja najveći broj sportista, sportskih radnika, volontera i drugih učesnika u njihovoj organizaciji podrazumevaju da se na jednom mestu okupe pojedinci, zajednice i države, gde se pored sportskog nadmetanja premošćuju kulturne, etničke i nacionalne podele. Menadžment timovi Organizacionih komiteta država domaćina Olimpijskih igara koji su bili zaduženi za bezbednost održavanja Olimpijskih igara tokom istorije modernih Olimpijskih igara susretali se sa različitim izazovima. Tokom 120 godina održavanja modernih Olimpijskih igara prateći događaji diktirali su povećanje mera bezbednosti na njima, a posledično i povećanje bezbednosnih zahteva (Šiljak i sar., 2016).

Za bezbednost Olimpijskih igara planiraju se i izdvajaju ogromni resursi, ali nije moguće predvideti i realno izračunati svaku moguću kriznu situaciju. Proces planiranja je komplikovan, odluke i rizici koji se donose moraju biti prioritet, jer je nemoguće zaštititi se od svakog scenarija. Opasnosti koje treba preduprediti i koje pripadaju oblasti bezbednosnog menadžmenta Olimpijskih igara kao najvećeg sportskog događaja na svetu, podrazumevaju:

- terorizam,

- kriminal,

- domaći ekstremizam i javni neredi,

- prirodne katastrofe,

- druge katastrofe,
- građanska neposlušnost,

- tehnološki rizici,

- saobraćaj,

- velike saobraćajne nesreće,

- kontrola vazdušnog prostora,

- bezbednost takmičara tokom nadmetanja od povreda

- preventivna zdravstvena bezbednost sportista uzokovana pandemijom COVID-19.

Analiza potencijalnih rizika menja se u zavisnosti od lokacije Olimpijskih igara. Jedan od odlučujućih faktora koji utiče na bezbednost planiranja Igara je geografski, odnosno, geopolitički položaj zemlje koja je domaćin Igara. Tako Zimske Olimpijske igre, koje su zasnovane na manjem broju učesnika kao i činjenica da se uglavnom održavaju u udaljenim i manje pristupačnim gradovima, smatraju se manje rizičnim u odnosu na Letnje Olimpijske igre i drugačije se planiraju.

Do danas se terorizam, kao pretnja celom svetu, pa i Olimpijskim igrama svakako smatrao prioritetnom opasnošću, pred kojom se se sve svetske bezbednosne agencije udruživale u cilju njegovog sprečavanja.

Kako se zbog pandemije COVID-19 održavanje Olimpijskih igara u Tokiju odložilo za ovu godinu (2021), iako će se odvijati pod nazivom Tokio 2020, nametnuo se veliki broj pitanja koji se tiču organizacionog dela održavanja najvećeg sportskog događaja na svetu. Pojava i prisustvo globalne pandemije COVID-19 je iznelo u prvi plan pridržavanje mera koje se odnose na zdravlje svih učesnika Olimpijskih igara, kako takmičara, tako i svih ostalih sportskih radnika i šire javnosti. Pitanja zdravstvene zaštite i bezbednosti uz istovremeno vođenje računa o potencijalnim finansijskim rizicima, razmatraju se u okviru projekta menadžmenta rizicima. Pripremajući ovaj sportski događaj organizator teži da eliminiše ili svede na najmanju moguću meru događaje ili aktivnosti koji mogu poremetiti učesnike događaja (takmičare, gledaoce ili službenike).

Organizacioni komitet Igara u Tokiju u dogovoru sa Međunarodnim olimpijskim komitetom potvrdio je ovogodišnje održavanje Olimpijskih igara, iako su rezultati prošlogodišnje ankete koja je sprovedena među građanima Japana da izraze svoj stav o održava- 
nju Olimpijskih igara u Tokiju pokazali da je čak preko $70 \%$ njih bilo protiv održavanja Igara (Blic, 2020).

Vremensko trajanje i geografska rasprostranjenost pandemije COVID-19 navodi da možemo reći da predstavlja modernu krizu i kao takva predstavljaja izazov za menadžere, stavljajući na probu sposobnosti pojedinaca, timova i celih organizacija u svim segmentima života, tako i u sportskom (Milašinović i sar., 2010). Međutim, organizovanje Igara u Tokiju, upravo zbog činjenice da se održavaju tokom trajanja pandemije COVID-19, pored već navedenog menadžmenta potencijalnim rizicima, mora da obuhvati postulate kriznog menadžmenta. To podrazumeva da organizatori moraju prihvatiti ovaj izazov i ostvariti najširu moguću saradnju i partnerstvo u traženju kreativnih odgovora, budući da prihvatanje fatalističke alternative za organizovanje ovog sportskog događaja, ne postoji kao opcija.

\section{MATERIJALI I METODE / MATERIALS AND METHODS}

Od izbijanja pandemije COVID-19 i donošenja odluke o odlaganju održavanja Olimpijskih igara u Tokiju, nakon savladavanja egzistencijalnog straha svakog pojedinca, sagledavanjem i praćenjem preporuka odgovornih tela, kako na lokalnom i regionalnom, tako i na globalnom nivou, nametnula su brojna pitanja oko održavanja Olimpijskih igara u Tokiju.

Predmet ovog istraživanja se upravo odnosi na menadžment sportskih organizacija i organizacionog komiteta za Olimpijske igre u Tokiju pod uticajem COVID-19. Cilj istraživanja je da se kroz analizu rada menadžmenta sportskih organizacija i komiteta sagleda i razume aktuelni problem pandemije COVID-19 i da se kreirane i preduzete mere usvoje i primene i kod organizovanja drugih velikih sportskih događaja.

I pored činjenice da su i Međunarodni olimpijski komitet i Organizacioni komitet Olimpijskih igara Tokio 2020, potvrdili organizaciju/održavanje Igara u julu 2021. godine javnost i dalje postavlja pitanje da li će se ove Igre ipak održati, odložiti ponovo ili čak otkazati. Međutim, kako su svi subjekti uključeni u njihovu organizaciju aktivni, nametnula su se istraživačka pitanja:

1. Koje organizacije su kreirale dokumenta koja se odnose na bezbednost svih učesnika tokom održavanja Ol od Covid-19?

2. Da li preporuke mogu garantovati bezbednost akterima Olimpijskih igara od Covid-19?

3. Da li usvojene mere i preporuke mogu biti primenjene i na organizaciju drugih sportskih događaja?
$\mathrm{U}$ ovom istraživanju je primenjen metod teorijske analize, imajući u vidu da upravo iz razloga prisutne pandemije COVID-19, svi naučni radovi koji se bave ovom problematikom kao i dokumenti koji se odnose na strategiju održivosti sporta/sportskih događaja ili preporuke mera bezbednosti mogu se naći u elektonskom formatu.

\section{REZULTATI I DISKUSIJA / RESULTS AND DISCUSSION}

Olimpijski pokret kao fenomen čine Međunarodni olimpijski komitet, međunarodne sportske organizacije i nacionalni olimpijski komiiteti. lako je prevashodna odgovornost Međunarodnog olimpijskog komiteta nadgledanje organizacije Olimpijskih igara, uloga i značaj ove sportske organizacije su mnogo šireg i značajnijega karaktera za sport vodeći se fundamentalnim principima olimpizma - od podsticanja etike i dobrog upravljanja u sportu, obrazovanja mladih kroz bavljenje sportom, podržavanja fer plej takmičenja bez nasilja, pa do podrške unapređenju položaja žena u sportu, borbe protiv dopinga, mera zaštite zdravlja sportista i dr.

Misija Međunarodnog olimpijskog komiteta među 18 navedenih ciljeva u čl. 2 Olimpijske povelje između ostalog obuhvata:

- da podstiče i podržava organizaciju, razvoj i koordinaciju sporta i sportskih takmičenja (stav 2),

- da sarađuje s nadležnim javnim ili privatnim organizacijama i vlastima u nastojanju da sport stavi u službu čovečanstva i na taj način promoviše mir (stav 4),

- da podstiče i podržava mere u vezi s medicinskom negom i zdravljem sportista (stav 10),

- da podstiče i podržava napore sportskih organizacija i javnih vlasti da obezbede socijalnu i profesionalnu budućnost sportista (stav 12),

- da podstiče i podržava odgovornu brigu za pitanja životne sredine, da promoviše održivog razvoja u sportu i zahtevati da se olimpijske igre održavaju u skladu s tim (stav 14) i

- da promoviše bezbedan sport i zaštitu sportista od svih oblika uznemiravanja i zloupotreba (stav 18) (IOC, 2020).

Oko šest meseci nakon pojave pandemije COVID-19 Međunarodni olimpijski komitet je potpisao dokument o partnerstvu sa Svetskom zdravstvenom organizacijom (WHO) i sa Ujedinjenim nacijama u cilju očuvanja zdravlja sportista i primeni preventivnih mera za smanjenje širenja i uticaja COVID-19 (Šiljak i sar., 2021). Pored toga, MOK je okupio međunarodni tim stručnjaka za respiratorne 
bolesti i formirana je tzv. „Medicinska COVID-19 baza" u cilju pružanja medicinske nege sportistima, ali i validnih informacija zasnovanih na stvarnim podacima (Ibid).

lako se istraživanje odnosi na sportske organizacije koje su direktno involvirane u organizaciju Olimpijskih igara u Tokiju, značajno je napomenuti da su Ujedinjene nacije, kao globalna svetska organizacija u kojoj je sport tek jedan segment kojim se ona bavi, 1. decembra 2020. godine izdala Rezoluciju na koju je ukazao Tomas Bah, predsednik Međunarodnog olimpijskog komiteta u svom pozdravnom govoru prilikom otvaranja 137 . sednice Skupštine MOK koja je održana 10. marta 2021. godine online (IOC, 2021, Opening Speech).

Rezoluciju/dokument pod nazivom „Bolje obnavljanje: sport za razvoj i mir - Ponovno otvaranje, oporavak i otpornost nakon COVID-19“ su objavile UN u želji da ukažu na neophodnu održivost razvoja sporta tokom prisutne pandemije (UN, COVID-19 Response, 2020). Sadržaj ovog dokumenta iznosi viziju za podršku ponovnom otvaranju, oporavku i otpornosti sporta. Navedene su posledice i predstavljen je kritičan presek situacije bavljenja vrhunskim sportom, zatim, uskraćenom fizičkom aktivnošću omladine zbog nepohađanja nastave iz bezbednosnih razloga. $U$ cilju dostizanja individualnog i kolektivnog blagostanja u smislu bavljenja sportom dati su predlozi za rešavanje navedenih problema i posledica uticaja COVID-19 na sport kroz četiri ključne oblasti - promovisanje ljudskih prava i borba protiv diskriminacije; obezbeđivanje jednakog pristupa sportu i fizičkoj aktivnost; zaštita učesnika i osiguravanje integriteta u sportu. Predstavljena vizija zahteva saradnju između država članica, civilnog društva, privatnog sektora i drugih zainteresovanih strana, kako bi se maksimizirao doprinos sportu kroz ostvarenja ciljeva održivog razvoja sporta kroz rad sa stručnjacima, partnerima, vladinim zvaničnicima i drugim zainteresovanim stranama u srodnim oblastima (Ibid).

$\mathrm{U}$ pomenutom pozdravnom govoru Tomas Bah je na 137. Skupštini MOK izvestio da MOK zajedno sa Organizacionim komitetom Ol Tokio 2020 i Japanskim partnerima radi punom parom kako bi odložene Olimpijske igre Tokio 2020 učinile sigurnom manifestacijom mira, solidarnosti i otpornosti čovečanstva u prevazilaženju pandemije (IOC, 2021).

Stav MOK je da Tokio je najbolje pripremljen olimpijski grad ikada i u ovom trenutku nemaju razloga za sumnju da će se ceremonija otvaranja održati 23. jula 2021. godine. Čelnici MOK izražavaju zahvalnost Vladi Japana, Tokijskoj metropolitanskoj vladi, organizacionom odboru, sportistima, međunarodnim sportskim organizacijama, NOKima, svim TOP partnerima i emiterima koji se bave pravima i time zadržavaju nepokolebljivu posvećenost uspehu Olimpijskih igara. Iz tog razloga napori MOK su usmereni na to kakve mere predostrožnosti preduzeti u borbi sa COVID-19. U ovom kontekstu su zajedno sa japanskim partnerima i prijateljima razvili sveobuhvatne i na nauci zasnovane knjige protivmera COVID-19 tokom održavanja Olimpijskih igara. Mere se kreću od imigracije zahtevima, do testiranja, socijalnog udaljavanja, traženja kontakata, vakcinacije i mnogih drugih.

Tehnički saveti koje MOK dobija od naučne zajednice, od SZO i od zdravstvenih stručnjaka širom sveta su veoma važni. Imperativ je da se svi moraju voditi naukom i činjenicama. Takođe će uspostaviti specifične protivmere koje se primenjuju na sve različite grupe koje učestvuju na Olimpijskim igrama: sportisti, pratnja, zvaničnici, dobrovoljci, sponzori, mediji, gledaoci i, naravno, domaćini Japanci. Radne grupe koje su angažovane u osmišljavanju knjiga vodiča za zaštitu od virusa marljivo rade ogroman posao i razmatraju rešenja kako će svaka od ovih grupa međusobno komunicirati kako bi svi bili sigurni.

Organizacioni odbor Olimpijskih i Paraolimpijskih igara u Tokiju (Tokio 2020) priprema se za bezbedno održavanje Igara Tokio 2020 u saradnji sa japanskom vladom. Pripremili su letak u saradnji sa Centrom za podršku volonterima Fondacije Nippon o protivmerama COVID-19 koje će terensko osoblje sprovoditi kako bi se bezbedno održale Igre u Tokiju 2020. Ovaj letak je kreiran na trenutnim novim merama za kontrolu koronavirusa. U slučaju da dođe do promena informacija, koje se dele, letak će biti ažuriran i na vreme dostavljen svim učesnicima Olimpijskih igara.

Pored toga, u cilju pomoći i preduzimanja tih mera biće distribuirani sledeći predmeti:

- Dve originalne navlake za lice (maske) kompanije ASICS

- Prenosni dezinficijens za ruke iz Centra za podršku volonterima Fondacije Nippon i

- Smernice za upravljanje situacijom (Tokyo 2020).

Kako bi organizatori osigurali da svi učesnici Olimpijskih i Paraolimpijskih igara i stanovnici Tokija i Japana budu sigurni i zdravi ovog leta, osmišljene su tzv. „Playbooks“, odnosno brošure koje su osnova kolektivnog plana Igara. Zajednički su in razvili Međunarodni olimpijski komitet, Međunarodni paraolimpijski komitet i Organizacioni komitet Tokija 2020. Zasnivaju se na opsežnom radu Radne grupe za sve partnere, koja takođe uključuje Svetsku zdravstvenu organizaciju, Vladu Japana, Tokijsku 
gradsku vladu, nezavisne stručnjake i organizacije iz celog sveta.

Prve verzije, objavljene početkom februara 2021. godine, iznosile su odgovornosti svih učesnika igara i pravila koja se moraju poštovati - počev od 14 dana pre putovanja, ulaska u Japan, na Igre i napuštanja Japana.

Druge verzije pružaju ažurirane smernice i dalje detalje o tome kako će Igre biti organizovane, tako da sportisti i svi učesnici na Olimpijskim igrama mogu da finaliziraju i primene svoje planove.

U junu će treća i poslednja planirana verzija Plaibook-a pružiti ažuriranja o svim značajnim promenama i rešiti sva otvorena pitanja IOC (2021).

Brošure su osmišljene za sledeće kategorije aktera Olimpijskih igara u Tokiju:

1. Sportisti i zvaničnici,

2. Međunarodne sportske asocijacije/federacije,

3. Olimpijska i Paraolimpijska porodica,

4. Marketing partneri,

5. Emiteri,

6. Reporteri,

7. Radno osoblje.

Za globalno funkcionisanje sportskih aktivnosti i sportskih događaja neophodna je usklađena saradnja svih entiteta Olimpijskog pokreta u skladu s njihovim nadležnostima. Svaka granska međunarodna sportska asocijacija je nadležna za verifikovanje ostvarenih kvalifikacionih normi sportista u svom sportu. Ovo je značajno iz razloga što usklađenijeg primenjivanja preventivnih mera zaštite sportista tokom organizovanja i održavanja sportskih događaja.

Međunarodne sportske organizacije/asocijacije su organizovale preko 270 velikih sportskih događaja, što podrazumeva svetska prvenstva ili svetske kupove, od septembra 2020 do marta 2021. godine. Kumulativno, u ovim događajima je učestvovalo preko 30.000 sportista. Svi su imali rigoroznu zdravstvenu kontrolu i pratili su postojeće sigurnosne protokole, uključujući opsežne režime ispitivanja, koji su premašili broj od 200.000 testova. Ni jedan od ovih događaja nije se pretvorio u širenje virusa, što je pokazatelj da je moguće organizovati velike međunarodne sportske događaje sa velikim brojem međunarodnih učesnika uz zaštitu zdravlja svih aktera.

Nacionalni Olimpijski Komiteti imaju svoja prava i obaveze koji su određeni Olimpijskom Poveljom. Prema čl. 27 Olimpijske povelje, misija NOK-a je da razvija, promoviše i štiti Olimpijski pokret u svojoj zemlji, a u skladu sa Olimpijskom Poveljom (IOC, 2020). Uloga NOK-a je sledeća:
- da neguje osnovne principe i vrednosti Olimpizma u svojoj zemlji, posebno u oblasti sporta i obrazovanja, promovisanjem programa Olimpijskog obrazovanja i vaspitanja na svim nivoima škola, Univerziteta i sportskih institucija; kao i da se zalaže za stvaranje institucija koje su posvećene Olimpijskom obrazovanju, posebno Nacionalne Olimpijske Akademije, Olimpijskog Muzeja, kao i drugih programa, uključujući kulturne, a u vezi sa Olimpijskim pokretom;

- da obezbeđuje poštovanje Olimpijske Povelje u svojoj zemlji;

- da podstiče razvoj vrhunskog sporta, kao i "sporta za sve“;

- da pomaže obučavanje kadrova koji rade u sportskoj administraciji i to organizovanjem kurseva i obezbeđivanjem da ti kursevi doprinose propagiranju osnovnih principa Olimpizma;

- da preduzima mere protiv svakog oblika diskriminacije i nasilja u sportu;

- da usvoji i primenjuje Svetski Anti-doping Kodeks.

- da podstiče i podržava mere koje se odnose na medicinsku negu i zdravlje sportista.

lako se pristup rešavanju problema pandemije COVID-19 razlikuje po državama, angažovanost Nacionalnih olimpijskih komiteta morala je biti usklađena sa preporukama MOK i Međunarodnih granskih sportskih asocijacija, na osnovu transparentnih informacija, radi primene mera zaštite zdravlja svojih sportista.

Ukupno 206 Nacionalnih olimpijskih komiteta su članovi MOK. Prateći dostupnost informacija svih 206 NOK-ova koje su upravo zbog COVID-19 očekivane na zvaničnim web stranicama u cilju informisanja kako vrhunskih, tako i drugih sportista, predstavljao bi težak zadatak prvenstveno zbog jezičke barijere, a potom i zbog svog obima, što može da ostavi prostor za dalja istraživanja na ovu temu. Iz tog razloga izabrani su reprezentativni primeri NOK-ova Grčke, Francuske, Velike Britanije i Australije vodeći se činjenicom da su ove četiri države od obnavljanja modernih Olimpijskih igara 1896. godine u Atini - jedine države koje su učestvovale na svim do sada doržanim Igrama (Šiljak, 2013).

Grčki olimpijski komitet (Hellenic Olympic Committee) na svom web-sajtu upućuje svoje sportiste na:

- Pruručnik MOK koji je u pripremi za OI,

- Prve smernice Međunarodne organizacije rada (ILO) za Covid-19 i Olimpijske igre u Tokiju, jer Grčki olimpijski komitet pored 
zdravlja sportista želi da zaštiti zdravlje svog osoblja i članova,

- Grčki olimpijski komitet preduzima još jedan korak kako bi "zaštitio" zdravlje radnika i organizuje „Samit ILO 2021“,

- Vebinar za sportiste i trenere pod nazivom „COVID-19 i sportska psihologija“,

- Preventivne nere tokom ceremonija,

- Uputstvo za nosioce olimpijskog plamena (baklje) u cilju zaštite od COVID-19,

- Istraživanje Evropskog olimpijskog komiteta o uticaju COVID-19 na sport

(https://hoc.gr/).

Francuski olimpijski komitet (Comité National Olympique et Sportif Français) je na svojoj oficijelnoj web stranici ima najveći broj dostupnih dokumenata koji se tiču zaštite od pandemije COVID-19 (https:// olympics.com/ioc/france). Među njima su dokumenti:

- Uredba od 10. jula 2020. kojom se propisuju opšte mere za zbrinjavanje epidemije Covid19 u okviru vanrednog stanja,

- Veliki broj pratećih dokumenata dostupan za preuzimanje,

- Opšte mere koje treba preduzeti za epidemiju Covid-19 na teritorijama vanrednog stanja ,

- Dokumenta iz pojedinih saveza sportskih timova,

- Uticaj pandemije COVID-19 i mere hitne medicine u sanitarnoj krizi na funkciju sportskih saveza i sportskih udruženja pravni aspekti,

- Protokol za povratak u škole - Školski sport,

- Vodič za preporuku sportske opreme, lokacija i prostora za vežbanje tokom pandemije COVID-19.

Olimpijski komitet Velike Britanije (British Olympic Association) na svojoj oficijelnoj web stranici nema dostupan ni jedan dokument koji se odnosi na zaštitne mere sportista ili sportskih radnika od COVID-19 (https://olympics.com/ioc/great-britain). $\mathrm{Na}$ sajtu se nalaze samo 2 informacije u okviru vesti:

- Izjava BOA o COVID-19 da im je imperativ očuvanje takmičarskog integriteta sportista, ali u okviru relevantnih vladinih i javnih smernica. Dalje, navode da će pratiti smernice vlade, Svetske zdravstvene organizacije i Javnog zdravlja u Engleskoj u praćenju svake tekuće promene saveta tokom predstojećih meseci i

- Veoma skromna izjava šefa medicinskog tima tima GB koji podržava zajednice i sportiste kroz pandemiju COVID-19 (Ibid).

Pod pretpostavkom prethodnih izjava da su britanski sportisti na neki način informisani o proto- kolu i merama prevencije od COVID-19, zapanjujuća činjenica je da ne postoje transparentni i dostupni podaci na web stranici njihovog nacionalnog olimpijskog komiteta, što kao posledicu može da ima nedovoljnu informisanost drugih sportista jer $u$ skladu sa načelima Međunarodnog olimpijskog komiteta, uloga nacionalnih olimpijskih komiteta se odnosi i na edukaciju sportista, u ovom slučaju, na zdravstvenu edukaciju.

Veoma slična situacija je i sa zvaničnom web stranicom Australijskog olimpijskog komiteta (Australian Olympic Committee Inc.) gde se samo u okviru vesti mogu naći pojedine aktivnosti ovog nacionalnog olimpijskog komiteta (Olimpijski komitet Australije, 2021) i to:

- AOC zahvaljuje olimpijskoj porodici na podršci australijskoj zajednici tokom COVID19 ,

- AOC planovi za bezbednost sportista i zvaničnika u svetu COVID-19,

- AOC najavljuje mere za suzbijanje COVID19 koje se odnose na protokol organizatora Ol.

Analizom rada ova četiri nacionalna olimpijska komiteta može se ustanoviti da su činjenice na strani rada nacionalnih olimpijskih komiteta Grčke i Francuske, dok se nacionalni olimpijski komiteti Velike Britanije i Australije oslanjaju na protokol i preporuke organizatora OI ili smatraju te informacije poverljivim. Kako nije u pitanju tajnost trenažnog procesa sportista već globalna zaštita svih sportista i drugih aktera Olimpijskih igara, kao i obaveza informisanja drugih sportista, ovakav njihov stav se može smatrati neprofesionalnim i nekorektnim.

Međutim, ne sme se ignorisati anagažovanost nacionalnog olimpijskog komiteta SAD (United States Olympic \& Paralympic Committee) koji je odmah po izbijanju pandemije, još 28.04.2020. godine objavio dokument koji je pripremio njihov medicinski tim na 13 stranica koji sadrži uputstva i preporuke za sve sportiste (Olimpijski komitet SAD, 2021). Činjenica koja ga u pozitivnom kontekstu izdvaja od ostalih analiziranih nacionalnih komiteta je ta da želeći da pomognu svojim sportistima i sportskim organizacijama u sprovođenju trenažnog i takmičarskog procesa pod što bezbednijim uslovima, naglašavaju da dokument smatraju samo smernicom za dalje prilagođavanje i primenu nakon analize i konsultacija drugih dokumenata od značaja za svaku sportsku granu ponaosob.

Olimpijski komitet Srbije je od pojave pandemije COVID-19, redovno informisao sve sportiste o preduzeminju preventivnih mera za očuvanje zdravlja od COVID-19. U saradnji sa lekarima sportske medicine date su preporuke i organizovana je online 
edukacija, gde su sportisti mogli da postavljaju pitanja medicinskom timu i da dobiju odgovore na njih. Takođe, Bilo je organizovana i vakcinacija kojoj je takođe prethodila mogućnost konsultacije sa lekarima. Informacije koje se dostupne svima na zvaničnoj web stranici Olimpijskog komiteta Srbije su veoma koncizno predstavljene.

Cilj COVID-19 protokola Olimpijskog komiteta Srbije je da postavi medicinski i operativni okvir koji će članovi Misije OKS poštovati, kako bi se osigurala bezbednost svih učesnika, a koji treba da pokrije biološku sigurnost svih učescnika, higijenu, testiranje i medicinsko upravljanje u datim okolnostima (OKS, 2021). OKS ukazuje da bi se umanjio rizik od Covid 19 infekcije, potrebno je temeljno planiranje i čvrst set smernica/protokola koji će zahtevati doslednu primenu, vođenu stručnom podrškom. Zbog stalnog menjanja znanja o Covid 19 infekciji, ovaj protokol će se razvijati i redovno ažurirati. Lokalne vlasti Japana za javno zdravlje stanovništva, mogu zahtevati i strožije mere od trenutno navedenih u ovom protokolu, što će možda biti tema dalje rasprave i razrade protokola. Osnovna činjenica sa kojom moraju biti upoznati svi članovi Misije OKS (sportisti, treneri, zvaničnici, tehničko osoblje) je da njihov odlazak na Olimpijske igre ne zavisi samo od ostvarene olimpijske kvalifikacione norme/kvote, već i potrebe da budu zdravi i negativni na COVID19 infekciju (Ibid).

Obavezne mere ponašanja tokom celog procesa - pred odlazak/tokom trajanja/period povratka sa Olimpijskih igara su sledeće:

- Nošenje maski u svim situacijama gde postoji mogućnost dolaska u kontakt s drugom osobom,

- U slučaju kontakta s drugom osobom, obavezno održavanje fizičke distance od 1,5 do $2 \mathrm{~m}$,

- Redovno i temeljito pranje ruku vodom i sapunom, minimum $20 \mathrm{~s}$,

- Izbegavanje dodirivanja očiju, nosa i usta,

- Praćenje dobre respiratorne higijene pokrivanje usta i nosa savijenim laktom prilikom kašljanja ili kijanja,

- Upotreba sredstava za dezinfekciju ruku na bazi alkohola,

- Izbegavanje boravka u zatvorenom prostoru gde boravi veći broj ljudi,

- Čišćenje opreme za trening/takmičenje pre i posle individualne upotrebe, korišćenje zasebnih peškira i flašica za vodu,

- Izbegavanje javnih mesta i javnih prevoza,

- Tuširanje u smeštaju pre i posle treninga i takmičenja,
- Ukoliko se sportista (drugo lice) ne oseća dobro (npr. groznica, kašalj, bol u grlu, otežano disanje...), obavezno treba da stupi u kontakt $\mathrm{s}$ imenovanim lekarom nacionalnog granskog sportskog saveza koji će stupiti u kontakt s dežurnim lekarom formirane Radne grupe OKS za praćenje svih aspekata COVID-19 infekcije na sportiste i članove Misije OKS.

Izvršni odbor Olimpijskog komiteta Srbije je na svojoj sednici, održanoj 25. decembra 2020. godine, formirao Radnu grupu za praćenje svih aspekata COVID-19 infekcije na sportiste i članove Misije OKS, a koja će biti glavno savetodavno telo Izvršnom odboru OKS i nacionalnim granskim sportskim savezima po pitanju ove infekcije. Ova radna grupa će praviti redovne koordinacione sastanke sa sledećim ciljevima:

1. Da se na adekvatan način smanji rizik od zaražavanja Covid 19 infekcijom,

2. Da sportisti koji su imali/preležali Covid 19 infekciju, imaju adekvatan povratak u trenažni/takmičarski proces,

3. Da se skrene pažnja na poštovanje predloženog protokola, koji će u zavisnosti od epidemiološke situacije, moguće pretrpeti i promene i prilagođavanja.

Pored prethodno navedenih mera, Olimpijski komitet Srbije je dao detaljan opis obaveznih mera pred polazak na put:

- Testiranje na prisustvo COVID-19 infekcije pred polazak na Olimpijske igre ( 3 testa $u$ određenim vremenskim intervalima),

- Testiranje na prisustvo COVID-19 infekcije po dolasku u Japan (testiranje po sletanju na Narita/Haneda aerodromu, testiranje po ulasku u Olimpijsko selo i testiranje pred svaki trenažni/takmičarski nastup na olimpijskim objektima),

- Testiranje po povratku za Beograd,

- Predtakmičarsko ponašanje za prevenciju COVID-19 infekcije,

- Obavezni zdravstveni pregledi sportista u Zavodu za sport i medicinu sporta,

- Procedura međunarodnog putovanja prema Japanu,

- Procedura u slučaju pojave simptoma COVID-19 infekcije (OKS, 2021).

\section{ZAKLJUČAK / CONCLUSION}

Rezultati rada ukazuju da se veliki broj sportskih i drugih globalnih organizacija angažovao na kreiranju dokumenata kako o strategiji održivosti sporta, tako i o protokolu tokom organizovanja sportskih događaja i brošurama sa preventivnim merama u cilju 
zaštite sportista i sportskih radnika od pandemije COVID-19. Tako su u izradi brojnih pomenutih uputstava i preporuka u saradnji sa medicinskim timovima učestvovali menadžment timovi MOK, Organizacionog komiteta OI Tokio 2020, svetskih sportskih asocijacija, nacionalnih olimpijskih komiteta, SZO, UN kao i mnogi drugi. Organizovanje Igara u Tokiju, upravo zbog činjenice da se održavaju tokom trajanja pandemije COVID-19, pored već navedenog menadžmenta potencijalnim rizicima, obuhvatilo je postulate kriznog menadžmenta, gde su organizatori prihvativši ovaj izazov ostvarili najširu moguću saradnju i partnerstvo u traženju kreativnih odgovora, budući da prihvatanje fatalističke alternative za organizovanje ovog sportskog događaja, ne postoji kao opcija. Preporuke koje su na snazi za učestvovanje na OI u Tokiju mogu u velikoj meri da garantuju bezbednost akterima Olimpijskih igara od COVID-19, imajući u vidu činjenicu da tokom trajanja pandemije COVID-19 je preko 30000 sportista učestvovalo na velikim sportskim događajima, gde se ni jedan od ovih događaja nije se pretvorio u širenje virusa, što je pokazatelj da je moguće organizovati velike međunarodne sportske događaje sa velikim brojem međunarodnih učesnika uz zaštitu zdravlja svih aktera. Evidentno je da sportske organizacije veoma kvalitetno sarađuju i razmenju iskustva poštujući nauku i validne činjenice kako bi se usvojene mere i preporuke mogle primeniti na organizaciju svih sportskih događaja.

\section{LITERATURA / REFERENCES}

[1] Blic portal (2020). Tokio neće Olimpijske igre! J.D.M. od 20.07.2020. Dostupno na https://sport.blic.rs/ostali-sportovi/japanci-nezele-odrzavanje-olimpijskih-igara-2021-zbogkorona-virusa/7ycxz47.

[2] IOC (2020). Olympic Charter - Mission and Role of the IOC, Lausanne: DidWeDo S.à.r.l., pp. 16-17.

[3] IOC (2020). Olympic Charter - National Olympic Committees, Lausanne: DidWeDo S.à.r.l., p. 60.

[4] IOC (2021). Opening Speech of Thomas Bach (IOC President) at the 137th IOC Session, 10 March 2021. Available at https://stillmedab.olympic.org/media/Document\% 20Library/OlympicOrg/News/2021/03/IOC_ Session_speech_March_2021_welcome.pdf.

[5] IOC (2021). Tokyo 2020 Playbooks. Available at https://olympics.com/ioc/tokyo-2020-playbooks.

[6] Milašinović,S., Kešetović, Ž., Nadić, D. (2010). Moć i nemoć kriznog menadžmenta u suočavanju sa modernim krizama. Megatrend revija, 7(2), str. 275-292.

[7] Olimpijski komitet Australije (2021). Australian Olympic Committee Inc. Available at https://www.olympics.com.au/news/aocannounces-measures-to-counter-covid-19/.

[8] Olimpijski komitet Francuske (2021). Comité National Olympique et Sportif Français. Available at https://olympics.com/ioc/france.

[9] Olimpijski komitet Grčke (2021). Hellenic Olympic Committee. Available at https://hoc.gr/.

[10] Olimpijski komitet SAD (2021). United States Olympic \& Paralympic Committee. Available at https://www.teamusa.org/about-the-usopc

[11] Olimpijski komitet Srbije (2021). Olimpijski komitet Srbije. Dostupno na

https://oks.org.rs/covid-19-protokol-olimpijskogkomiteta-srbije/.

[12] Olimpijski komitet Velike Britanije (2021). British Olympic Association. Available at https://olympics. com/ioc/great-britain.

[13] Reade, J., Singleton, C. (2020). Sport: what could be the long-term effects of coronavirus? Economics Observatory (online), last updated on October 21, 2020. Available at https://www. coronavirusandtheeconomy.com/question/sportwhat-could-be-long-termeffects-coronavirus. Retrieved on March, 19, 2021.

[14] Šiljak, V. (2013). Olimpizam. Beograd: Alfa Univerzitet.

[15] Šiljak, V., Vukašinović, V., Đurović, D. (2016). Bezbednosni zahtevi Olimpijskih igara, Sportlogia (Banja Luka), 12(1), str. 30-39. doi:10.5550/sgia.161201.se.SVD

[16] Šiljak, V., Zrnzević, N., Stefanović, R., Perović A., Veselinović, J., Đurović, D., (2021). Uticaj COVID-19 na budućnost sporta: održivost $\mathrm{i}$ obnova, Ecologica, 28(101), str. 72-81.

[17] Tokyo 2020 (2021). Information about the COVID-19 countermeasures leaflet. Available at https://olympics.com/tokyo-

2020/en/games/volunteer-news/informationabout-the-covid-19-countermeasures-leaflet/.

[18] UN (2020). Recovering Better: Sport for Development And Peace - Reopening, Recovery and Resilience Post-COVID-19. Available at https://www.un.org/development/desa/dspd/wpcontent/uploads/sites/22/2020/12/Final-SDPrecovering-better.pdf. Retrieved on March, 20, 2021. 